Acta Regionalia et Environmentalica 2

Nitra, Slovaca Universitas Agriculturae Nitriae, 2016, pp. 41-46

\title{
LAND MARKET AND PRICE OF THE AGRICULTURAL LAND AFTER THE END OF THE TRANSITIONAL PERIOD
}

\author{
Katarína DIRGASOVÁ
}

Slovak University of Agriculture in Nitra, Slovak Republic

\begin{abstract}
After the end of the transition period for the purchase of the agricultural land by foreigners, the legislation regulating the acquisition of the agricultural land was adopted for the purpose of harmonization of the Slovak legislation with the legislation of the European Union. The Law no. 140/2014 Coll. on the acquisition of ownership to the agricultural land and amending and supplementing determines the subjects that are legitimated to acquire the ownership to the agricultural land. In addition, due to the creation of the Register of Offers of the Agricultural Land, the legislation allows the landowner to set a price on the sale of the agricultural land. In Slovakia, apart from the administrative prices and the market prices, there is a new type of prices, so-called "supply price". The aim of the paper is to sum up the impact of the current legislation on the land market and the prices of agricultural land.
\end{abstract}

Keywords: agricultural land, agricultural land market, administrative price, market price, supply price

The importance of the agricultural land as a production factor is mainly in its specific characteristics that distinguish it from other factors of production. These characteristics include limitedness, immobility and abrasion of land (Lazíková and Takáč, 2011). Since the land is one of humanity's most precious assets, which allows plants, animals and man to live on the earth's surface, it is the duty of the governments and those in authority to purposefully plan and administer land resources (European Soil Charter). The land must be protected from damage and the unfounded reduction of its acreage, quality and volume, since it is and it will remain the base of environmental, economic and social potential of the state (Dirgasová and Mandalová, 2015). Bandlerová et al. (2015) pointed out that the acquisition of land has always been, and not only in Slovakia but also in other countries, a delicate issue and definitely an area filled with tension. Legislative instruments of each country should secure the land protection so the countries should ensure that land would be in the hands of those who will protect and cultivate it (Lazíková and Bandlerová, 2014). After the accession to the European Union, Slovakia has applied the right resulting from the Treaty of Accession (2003), and due to the negotiations, Slovakia has obtained a temporary exemption relating to the free movement of capital (Swinnen and Vranken, 2009). During this transitional period, also known as the moratorium on the purchase of the agricultural land by foreigners, non-residents were not (officially) allowed to acquire the agricultural land in Slovakia. The transitional period ended on 30 th April 2014. After its end, foreigners can acquire agricultural land in the same way as Slovak citizens (Lazíková et al., 2015). However, the new legal regulation adopted due to the harmonisation of Slovak and European legislation, has influenced the land market as well as the prices of agricultural land in Slovakia.

\section{Material and methods}

The main aim of the paper is to evaluate the situation on the agricultural land market after the end of moratorium on the purchase of agricultural land by foreigners. In order to fulfil the main aim, two partial objectives were stipulated. The first one is to analyse the situation on the agricultural land market after the end of the transitional period with the special focus on the analysis of the agricultural land offered for sale via the Register of Offers of the Agricultural Land. The second partial objective is the comparison of the administrative prices, market prices and supply prices of agricultural land during one-year period after the end of the transitional period.

The data from the Register of Offers of the Agricultural Land were used for the statistical analysis of the development of agricultural land market. The data provide information on offers for sale of agricultural land (inter alia the information on the landowner, the information on the agricultural land plot and the information on the supply price of the agricultural land plot). The basic material for determination of the administrative price of the agricultural land was the Act no. 582/2004 Coll. on local taxes and local fees for municipal waste and minor construction waste. Annex 1 of this law sets the administrative price for each agricultural land plot, which was offered for sale via the Register of Offers of the Agricultural Land. The data on the market prices of agricultural land were obtained from the Research Institute of Agriculture and Food Economics. The comparison of prices on the Slovak agricultural land market is in the centre of attention of several authors, inter alia Bandlerová (2006), Buday and Grausová (2012), Duke et al. (2004), Pavličková and Spišiak (2007), 
Spišiak and Švoňavec (1999), Takáč and Lazíková (2013). The analysis of the agricultural land market by means of the agricultural land offered for sale via the Register of Offers of the Agricultural Land as well as the comparison of administrative prices, market prices and supply prices of agricultural land was realized by general scientific methods, methods of descriptive statistics, graphical methods and exploratory data analysis. In addition to the analytical tools of Excel, the STATA statistical software was used for the statistical evaluation.

\section{Results and discussion}

\section{Acquisition of agricultural land}

After the end of moratorium on the purchase of the agricultural land, the Act no. 140/2014 Coll. on acquisition of ownership to agricultural land and amending and supplementing (hereinafter referred to as the Law on acquisition to ownership to agricultural land) was adopted. It came into force on June 1, 2014. The aim of that legislation was to restrict the disposal of the agricultural land, which should be preferentially given to natural persons and legal entities that carry out agricultural production, either as their business or a profession.

Nowadays it is not possible to transfer property rights to agricultural land to anyone. Due to the protection and use of agricultural land, the Act on acquisition of ownership to agricultural land strictly defines a group of eligible subjects as well as the conditions that those subjects have to fulfil if they have an interest in acquisition of ownership to agricultural land. These conditions are valid for residents as well as non-residents. The basic conditions that must be fulfilled by potential acquirers are:

$\square$ permanent residence (in the case of natural person) or registered office (in the case of legal entity) in the territory of the Slovak Republic for at least 10 years before the acquisition of ownership of the agricultural land,

$\square$ carrying out the agricultural production as a business for at least 3 years before the acquisition of ownership of agricultural land.

Those who fulfil these conditions are known as qualified subjects.

A young farmer is an exception. He/she does not have to meet the requirement of carrying out the agricultural production as a business for at least three years. However, under the legal regulation, a young farmer is not allowed to sell, lease or donate the acquired agricultural land for three years from the date of its acquisition. The agricultural land can be also acquired by a natural person who for at least 3 years before the date of the conclusion of the contract on the transfer of ownership to the agricultural land carries out agricultural production in employment, a similar working relationship or in the employ for a person who carries out the agricultural production as a business.

The Act on acquisition of ownership to agricultural land also regulates the principle of priority of right to agricultural land according to territorial subsidiarity. Therefore, the group of the acquirers, who had to be asked first because they have a priority of right to become the landowners of agricultural land, was created. The first ones in the order are qualified subjects from the municipalities where offered agricultural land plot is registered. The second ones in the order are qualified subjects, who are interested in the offered land, coming from adjacent municipalities, and finally the qualified subjects regardless of the place of their business. The landowner of agricultural land may sell the agricultural land without any restrictions to a family member, a close person, a relative person, a co-owner of the agricultural land and the natural person or legal entity that carry out agricultural production as a business for at least 3 years before the acquisition of ownership to agricultural land in the municipality where offered agricultural land plot is registered.

The landowner of agricultural land has an obligation to publish his/her offer for the transfer of ownership to agricultural land in the Register of Offers of the Agricultural Land administered by the Ministry of Agriculture and Rural Development of the Slovak Republic (hereinafter referred to as the Register) for at least 15 days. Each offer contains these information: name / business name of the landowner, number of certificate of ownership, number of parcel of offered agricultural land plot, municipality and cadastral area, where the offered agricultural land plot is registered, soil type of offered agricultural land plot, total land area and offering land area of offered agricultural land in $\mathrm{m}^{2}$, period of publication (i.e. the period until which the offer is published in the Register), information whether the landowner publishes the offer for himself/herself or in mandate, price which the landowner wants for $1 \mathrm{~m}^{2}$, and finally the extent of publication (usually neighbouring municipalities). Drábik and Rajčániová (2014) pointed out that the price published in the Register is stipulated by the landowner of agricultural land. According to the Law on acquisition of ownership to agricultural land, it is not possible to bargain for the price. A potential acquirer should just accept it or reject it. The prices, which are published in the Register, cannot be considered as the market prices, since first of all it is not certain whether the potential acquirer will be found and subsequently, it is not sure whether he/she will be willing to accept the price published in the Register. As a consequence of the situation caused by the legislation, the new type of price was found in Slovakia. It is the so-called supply price of agricultural land.

\section{Agricultural land market}

During the one-year period from the date when the Act on acquisition of ownership to agricultural land came into force, i.e. from June 1, 2014 to May 31, 2015 (hereinafter referred to as the selected period), we have recorded and observed offers for the sale of agricultural land published via the Register. An overview of all these offers is presented in Table 1.

During the selected period, the total number of offers for sale of agricultural land published via the Register was 5811 (thereof 3266 offers for sale of the arable land; 40 offers for sale of vineyards; 1 offer for sale of hop gardens; 42 offers for sale of gardens; 6 offers for sale of orchards and 2456 offers for sale of permanent grassland). The total acreage of agricultural land offered for sale via Register was 2799.34 ha (thereof 2201.36 ha of arable land; 11.44 ha of 
Table 1 Overview of all offers for sale of the agricultural land published via the Register in NUTS III regions during the period from June 1, 2014 to May 31, 2015

\begin{tabular}{|l||c|c|c|c|}
\hline Region & $\begin{array}{c}\text { Number } \\
\text { of offers }\end{array}$ & $\begin{array}{c}\text { Total acreage of offered } \\
\text { agricultural land in ha }\end{array}$ & $\begin{array}{c}\text { Average acreage of offered } \\
\text { agricultural land plots in ha }\end{array}$ & $\begin{array}{c}\text { Share of the total offered agricultural land } \\
\text { on the total acreage of Slovakia in \% }\end{array}$ \\
\hline Bratislava & 864 & 265.73 & 0.31 & $9.49 \%$ \\
\hline Trnava & 375 & 106.74 & 0.28 & $3.81 \%$ \\
\hline Trenčín & 590 & 36.22 & 0.06 & $1.29 \%$ \\
\hline Nitra & 420 & 785.35 & 1.87 & $28.05 \%$ \\
\hline Žilina & 511 & 30.42 & 0.06 & $1.09 \%$ \\
\hline Banská Bystrica & 1870 & 634.18 & 0.34 & $22.65 \%$ \\
\hline Prešov & 725 & 188.17 & 0.26 & $6.72 \%$ \\
\hline Košice & 456 & 752.52 & 1.65 & $26.88 \%$ \\
\hline Slovakia & 5811 & 2799.34 & 0.48 & $100.00 \%$ \\
\hline
\end{tabular}

Source: own calculation according to the data from the Register of Offers of the Agricultural Land

* green $=$ the highest value; red = the lowest value (values are evaluated in columns)

vineyards; 0.36 ha of hop gardens; 3.80 ha of gardens; 2.87 ha of orchards and 579.50 ha of permanent grassland). To sum it up, during the selected period, the share of the total offered agricultural land on the total acreage of Slovakia was $0.12 \%$. The share of various types of offered agricultural land on the total acreage of these types was:

$\square 0.16 \%$ of arable land out of the total acreage of arable land in Slovakia,

$\square 0.04 \%$ of vineyards out of the total acreage of vineyards in Slovakia,

$\square 0.07 \%$ of hop gardens out of the total acreage of hop gardens in Slovakia,

$\square 0.005 \%$ of gardens out of the total acreage of gardens in Slovakia,

$\square 0.02 \%$ of orchards out of the total acreage of orchards in Slovakia,

$\square 0.07 \%$ of permanent grassland out of the total acreage of permanent grassland in Slovakia.

The average acreage of offered agricultural land was 0.48 ha. The largest fragmentation of agricultural land is in the regions with the lowest average acreage of offered agricultural land. On the basis of Table 1, it is evident that the fragmentation of agricultural land in the Trenčín region and the Žilina region is much higher than in other NUT III regions of Slovakia.

\section{Price of agricultural land}

Except of the information on the acreage of offered agricultural land, the Register also provides the information on the price of the agricultural land. The prices published via the Register cannot be considered as the official market prices of agricultural land. The reason for that is that it is not certain whether the potential acquirer would be found and whether he/she will be willing to accept the price demanded by the landowner of agricultural land (i.e. it is doubtful whether the transfer of ownership to the agricultural land would be realized in practice). For the purpose of this paper, these prices (i.e. the prices published via the Register) are referred to as the supply prices of agricultural land. The market prices of agricultural land were provided by the Research Institute of Agriculture and Food Economics, which has done research on the agricultural land market in selected regions of Slovakia. The data on the market prices were aggregated and converted to NUTS III regions for the purpose of this paper. Each offer published via the Register contains information enabling the precise identification of the agricultural land plot. This identification is subsequently the basis for determination of its price according to the

Table 2 Descriptive characteristics of the agricultural land prices in NUTS III regions during the period from June 1, 2014 to May 31, 2015

\begin{tabular}{|l|c|c|c|c|c|c|c|c|c|c|c|c|c|c|c|c|}
\hline \multirow{2}{*}{ Indicator } & \multicolumn{2}{|c|}{ BA } & \multicolumn{2}{c|}{ TT } & \multicolumn{2}{c|}{ TN } & \multicolumn{2}{c|}{ NR } & \multicolumn{2}{c|}{ ZA } & \multicolumn{2}{c|}{ BB } & \multicolumn{2}{c|}{ PO } & \multicolumn{2}{c|}{ KE } \\
\cline { 2 - 7 } & AP & SP & AP & SP & AP & SP & AP & SP & AP & SP & AP & SP & AP & SP & AP & SP \\
\hline \hline Average & 0.39 & 0.68 & 0.63 & 0.86 & 0.63 & 0.55 & 0.54 & 0.63 & 0.06 & 0.63 & 0.13 & 0.40 & 0.20 & 1.08 & 0.20 & 0.48 \\
\hline Minimum & 0.00 & 0.15 & 0.00 & 0.20 & 0.00 & 0.00 & 0.03 & 0.00 & 0.02 & 0.19 & 0.00 & 0.07 & 0.02 & 0.00 & 0.02 & 0.01 \\
\hline Maximum & 0.93 & 25.00 & 1.11 & 25.00 & 1.11 & 50.00 & 1.06 & 11.00 & 0.34 & 20.00 & 0.57 & 30.00 & 0.53 & 50.00 & 0.56 & 10.00 \\
\hline Median & 0.46 & 0.35 & 0.50 & 0.35 & 0.50 & 0.20 & 0.55 & 0.41 & 0.03 & 0.19 & 0.05 & 0.25 & 0.17 & 0.20 & 0.14 & 0.35 \\
\hline Variance & 0.03 & 2.07 & 0.09 & 5.02 & 0.09 & 5.42 & 0.07 & 0.72 & 0.01 & 1.92 & 0.02 & 1.67 & 0.02 & 29.22 & 0.02 & 1.30 \\
\hline Standard deviation & 0.18 & 1.44 & 0.29 & 2.24 & 0.29 & 2.33 & 0.27 & 0.85 & 0.08 & 1.38 & 0.14 & 1.29 & 0.13 & 5.41 & 0.14 & 1.14 \\
\hline
\end{tabular}

Source: own calculation according to the data from the Register of Offers of the Agricultural Land

* AP - administrative price (eur $\left.\mathrm{m}^{-2}\right)$; SP - supply price (eur $\left.\mathrm{m}^{-2}\right)$; ${ }^{* *} \mathrm{BA}$ - Bratislava region; TT - Trnava region; TN - Trenčín region; NR - Nitra region; ZA - Žilina region; BB - Banská Bystrica region; PO - Prešov region; KE - Košice region 


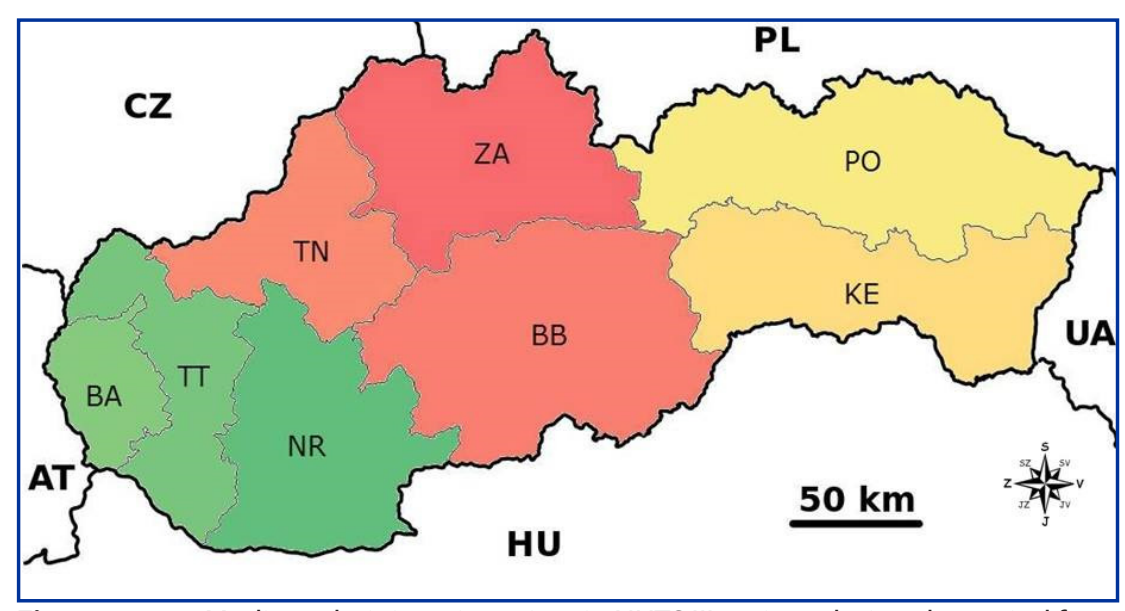

Figure 1 Median administrative prices in NUTS III regions during the period from June 1, 2014 to May 31, 2015

Source: own calculation

* green - the highest price; red - the lowest price (individual prices are shown in Table 2)

** BA - Bratislava region; TT - Trnava region; TN - Trenčín region; NR - Nitra region; ZA - Žilina region; $\mathrm{BB}$ - Banská Bystrica region; $\mathrm{PO}$ - Prešov region; KE Košice region

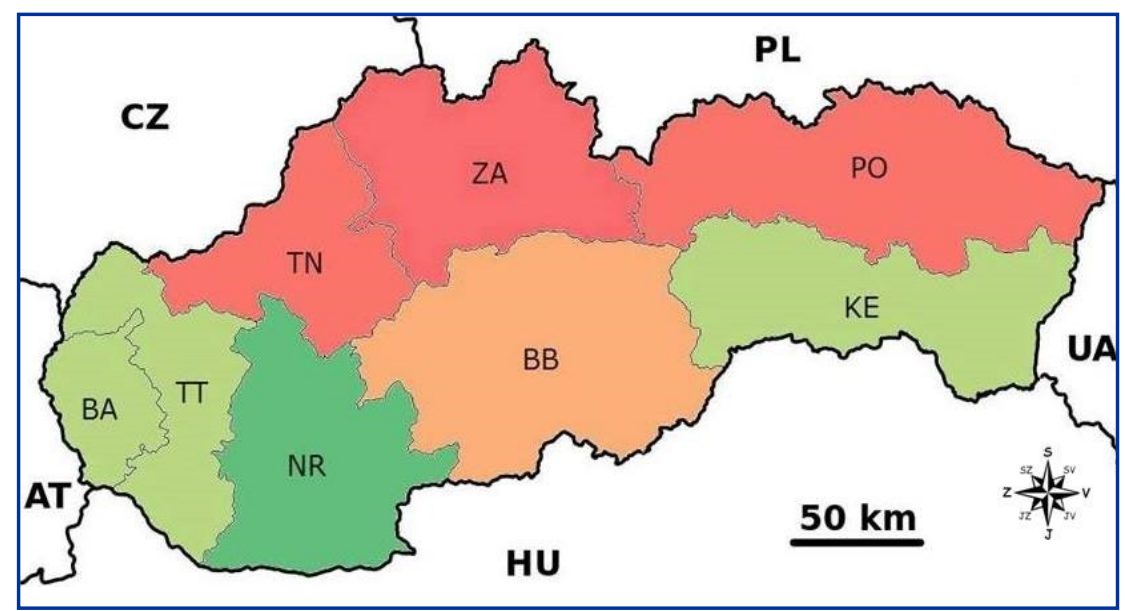

Figure 2 Median supply prices in NUTS III regions during the period from June 1, 2014 to May 31, 2015

Source: own calculation

${ }^{*}$ green - the highest price; red - the lowest price (individual prices are shown in Table 2)

** BA - Bratislava region; TT - Trnava region; TN - Trenčín region; NR = Nitra region; $\mathrm{ZA}=$ Žilina region; $\mathrm{BB}=$ Banská Bystrica region; $\mathrm{PO}=$ Prešov region; $\mathrm{KE}=$ Košice region

Act no. 582/2004 Coll. on local taxes and local fees for municipal waste and minor construction waste. The prices of agricultural land plots stipulated according to this law are referred to as the administrative prices of agricultural land. Table 2 presents the results of descriptive statistics, which was applied on the administrative prices and the supply prices of agricultural land offered for sale via the Register during the selected period.

A large variance of supply prices is a result of the outliers of this type
(5 000 eur ha-1) and the Bratislava region (4 600 eur ha $^{-1}$ ). All these regions are characterized by the highest quality of agricultural land due to their geographical location. On the contrary, the lowest median administrative prices of agricultural land are in the Žilina region (300 eur ha-1), i.e. in the NUTS III region with the lowest quality.

On the basis of Figure 2, it is evident that the rank of countries according to the median supply prices of agricultural land is in essence the same as in the case of the median administrative prices of agricultural land with the exception of the Košice region, Banská Bystrica region and the Prešov region. The first two regions increased due to higher supply prices of agricultural land. On the other hand, the Prešov region declined because of low supply prices. The highest median supply price of agricultural land is in the Nitra region (4 100 eur ha-1) and the lowest one is in the Žilina region (1 900 eur ha-1).

For the purpose of comparison of the administrative prices, market prices and supply prices of agricultural land, we used the date without the outliers, which were identified by explorative analysis. A comparison of average administrative prices, market prices and supply prices in NUTS III regions is presented in Figure 3.

The administrative price of agricultural land reflects mainly the quality of land. That is why the highest average administrative prices of agricultural land are in the Trnava region (6 308 eur ha-1) and the Nitra region (5 519 eur ha-1); and the lowest prices are in the Žilina region (718 eur ha ${ }^{-1}$ ). This division reflects the quality of land in Slovakia.

The market prices of agricultural land do not copy trends of the administrative prices. The highest average market price of agricultural land is in the Bratislava region (5 817 eur ha-1), despite the fact that the quality of land in this region is on the third rank out of all NUTS III regions in Slovakia. The second highest average market price is in the Trnava region (3 455 eur ha ${ }^{-1}$ ). The difference in the price of agricultural land in the Bratislava region and the Trnava region, where is the land with the highest quality is more than 2000 eur ha-1. The lowest average 


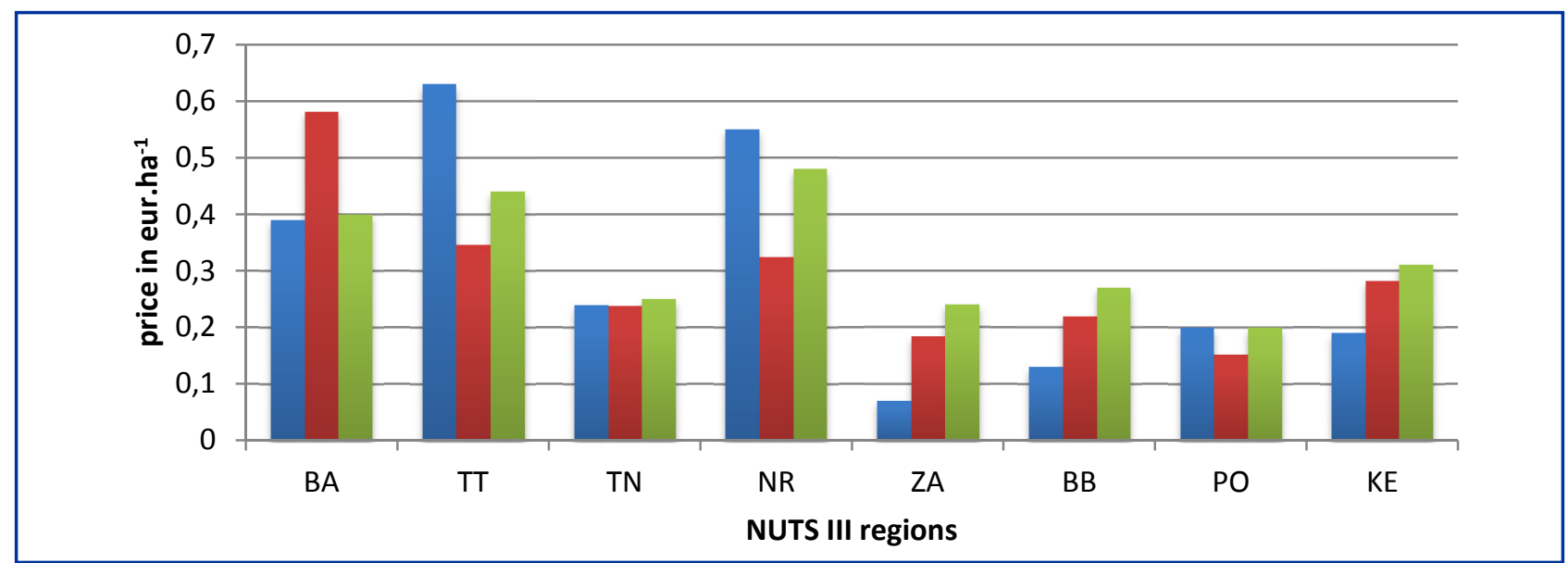

Figure 3 Average prices of agricultural land in NUTS III regions

Source: own calculation

* BA - Bratislava region; TT - Trnava region; TN - Trenčín region; NR - Nitra region; ZA - Žilina region; BB - Banská Bystrica region; $\mathrm{PO}$ - Prešov region; KE - Košice region

market price of agricultural land is in the Prešov region (1 526 eur ha-1). The average market prices are higher than the average administrative prices in almost all NUTS III regions, except for the Trnava region and the Nitra region, where the land is most fertile. The average administrative price of agricultural land is higher than the market price also in the Prešov region. Let us assume that the reason may be either a low demand for the agricultural land in this area or just the inaccuracy caused by the low number of offers published in that region. In the Trenčín region, the administrative prices of agricultural land are equal to the market prices.

The average supply prices of agricultural land are higher in all NUTS III regions except for the Trnava region and the Nitra region. The smallest difference between the average supply price and the average administrative price is in the Bratislava region and the Trenčín region. In average, the supply price of agricultural land is higher by 100 eur ha-1 than the administrative price. In the Prešov region, the average supply price is equal to the average administrative price (2 000 eur ha-1). The highest difference between the average supply price and the average administrative price is in the Trnava region, where the average supply price of agricultural land is by about 1900 eur ha-1 lower. The highest supply prices are in the Nitra region, Trnava region and the Bratislava region due to the fact that the landowners take into account not only the quality of land, but also the attractiveness of the region. The Bratislava region is considered the economically most developed region in Slovakia.

In case we did not excluded outliers of agricultural land prices and we took into account all supply prices published via the Register during the selected period, the results of our analysis would be absolutely different. In that case, the highest average prices of agricultural land would be in those NUTS III regions where the quality of land is low and where the land is used for other than agricultural purposes. An example would be the Žilina region, where the supply price of agricultural land is in average value of about 6000 eur ha-1.

\section{Conclusion}

The situation on the agricultural land market has been complicated due to the Act on acquisition of ownership to agricultural land. It largely restricts one of the fundamental rights - the right to own property. While the new regulations on acquisition of agricultural land makes the access of new subjects carrying out the business in the field of agriculture more difficult for both citizens of Slovakia as well as nonresidents, on the other hand, they significantly empower position of large agricultural enterprises, which can now gain a monopoly on the agricultural land in their region. The legal regulation also significantly narrows the group of subjects that can acquire agricultural land. All this leads to breaking the rules of economic competition. The Law on acquisition of ownership to agricultural land indirectly defines the group of "non-preferred subjects" that are directly excluded from the possibility to acquire the agricultural land in Slovakia. The legislation also introduced the principle of preference on the basis of territorial subsidiarity. The assumption that the closer location of acquirer's permanent residence or registered office to the agricultural land means better land management does not stand on an objective basis. A selection of potential acquirers of agricultural land based on the territorial subsidiarity as well as on the length of permanent residence (in the case of natural person) or registered office (in the case of legal entity) can be considered as discriminatory.

Due to the Act on acquisition of ownership to agricultural land, the landowner has an option to stipulate the price of agricultural land and publish it via the Register of Offers of the Agricultural Land. The acquirer has only two options; the price can be either accepted or rejected. In accordance with the current legislation it is not possible to bargain for the price. It is necessary to emphasise that a number of transfers of ownership to agricultural land is realized out of the Register, as the legislation provides the landowner with several exceptions, when he/she is not obliged to use the procedure of publishing the offers via the Register. Another important fact is that not each offer published via the Register must be accepted and therefore the transfer of ownership to agricultural land may not be realized. 
Therefore, it is necessary to make a difference between the supply price and the market price of agricultural land.

The comparison of the administrative prices, market prices and supply prices of agricultural land showed significant differences in the agricultural land prices. The administrative prices reflect the quality of agricultural land. The market prices are formed on the basis of supply and demand on the agricultural land market and therefore they are results of mutual agreements of the contracting parties. On the contrary, the supply prices of agricultural land, which appeared as results of the Act on acquisition of ownership to agricultural land, reflect just one part of the equation of the agricultural land supply. Even though the supply prices do not reflect actual market prices, they are extremely important. The supply prices help to fill in the deficit of information in the agricultural land prices. Any research in this branch of knowledge is extremely difficult because of the lack of information on the market prices of agricultural land. This type of information is subject to trade secret, thus there is no official statistics dealing with the official market prices of agricultural land prices in Slovakia.

\section{Acknowledgement}

The paper is an output of the project J. Monnet - Centre of Excellence "EU Land Policy - Pathway towards Sustainable Europe" DECISION: n. 2013-2883/001-001. Project no. 54260o-LLP-1-2013-1-SK-AJM-P.

\section{References}

BANDLEROVÁ, A. 2006. Cena pol'nohospodárskej pôdy. Presentation. Nitra:SPU, 2006. [online].2006. [cit. 2016-02-26]. Avalable at: <http:// www.google.sk/url?sa $=\mathrm{t} \& \mathrm{rct}=\mathrm{j} \& \mathrm{q}=\mathrm{cena} \% 20 \mathrm{po} \% \mathrm{C} 4 \%$ BEnohospod\%C3\%A1rskej\%20p\%C3\%B4dy\&source=web\&cd = 4\&ved=0CFQQFjAD\&url=http\%3A\%2F\%2Fbandlerova.weby.uniag.sk\%2Ffiles\%2Fagrarne\%2Fap9.ppt\&ei=GIfYTvHeC-jd4QTN9pH1DQ\&usg= AFQjCNFADiCKEj22EaLmaxVY4xQZYE_UTg\&cad=rja>

BANDLEROVÁ, A. et al. 2015. The current issues of agricultural land market in Slovakia $=$ A mezőgazdasági földpiac aktuális kérdései Szlovákiában. In Economica, vol. 8, 2015, no. 4. ISSN 1585-6216.

BUDAY, Š. - GRAUSOVÁ, G. 2012. Analýza trhu s pol’nohospodárskou pôdou vo vybraných okresoch Slovenska v roku 2011. In Ekonomika polnohospodárstva, vol. 12, 2012, no. 4. ISSN 1338-6336.
DIRGASOVÁ, K. - MANDALOVÁ, K. 2015. Impact of Legislative Imperfections on the Agricultural Land Market in Slovakia. In ICABR 2015. X. International Conference on Applied Business Research. Brno : Mendel University, 2015. ISBN 978-80-7509-379-0.

DRÁBIK, D. - RAJČÁNIOVÁ, M. 2014. Agricultural land market in Slovakia under the new land acquisition law. In Review of Agricultural and Applied Economics, vol. 27, 2014, no. 2. ISSN 1336-9261.

DUKE, J. M. - MARIŠOVÁ, E. - BANDLEROVÁ, A. - SLOVINSKÁ, J. 2004. Price repression in the Slovak agricultural land market. In Land Use Policy, vol. 21, 2004, no. 1. ISSN 0264-8377.

EUROPEAN Soil Charter. 1972. Council of Europe. Committee of Ministers. Resolution (72) 19.

LAZÍKOVÁ, J. - BANDLEROVÁ, A. 2014. Nadobúdanie vlastníckeho práva $\mathrm{k}$ polnohospodárskej pôde cudzincami na Slovensku: Acquisition of the properity rights to the agricultural land in Slovakia by the foreigners. In Výzvy a perspektívy agrárneho práva Európskej únie. Zborník z medzinárodnej vedeckej konferencie. Nitra : SPU, 2014. ISBN 978-80-552-1200-5.

LAZÍKOVÁ, J. - TAKÁČ, I. 2010. Právne a ekonomické aspekty nájmu pol'nohospodárskej pôdy. Nitra:SPU, 2010. ISBN 978-80-552-0447-5. LAZíKOVÁ, J. et al. 2015. Agricultural land market in Slovakia economic and legal impacts of the Law no. 140/2014 Coll. on the land acquisition. In Agricultural economics, vol. 61, 2015, no. 8. ISSN 0139-570X

PAVLIČKOVÁ, K. - SPIŠIAK, P. 2007. Formovanie trhu $\mathrm{s}$ pol'nohospodárskou pôdou $\mathrm{v}$ stredoeurópskom priestore. In Geographia Cassoviensis, vol. 1, 2007, no. 1. ISSN 1337-6748.

REGISTER of Offers of Agricultural Land. [online]. Avalaible at: $<$ https://pozemky.mpsr.sk/>

SPIŠIAK, P. - ŠVOŇAVEC, M. 1999. Regionálne rozdiely v cene polnohospodárskej pôdy na Slovensku. In Agricultural Economics, vol. 45, 1999, no. 6. ISSN 0139-570X.

SWINNEN, J. F. M. - VRANKEN, L. 2009. Land \& EU Accession: Review of the Transitional Restrictions by New Member States on the Acquisition of Agricultural Real Estate. Brusel : CEPS, 2009. ISBN 978-92-9079-827-9.

TAKÁČ, I. - LAZÍKOVÁ, J. 2013. The legal regulation on rental contracts on the land rental market in Slovakia - Právna úprava nájomných zmlúv na trhu s prenajímaním pôdy na Slovensku. In Agrárne právo EÚ, vol. 2, 2013, no. 1. ISSN 1338-6891.

TREATY of Accession of the Czech Republic, Estonia, Cyprus, Latvia, Lithuania, Hungary, Malta, Poland, Slovenia and Slovakia. 2003. 